\title{
Phytopathology
}

\section{Major Emerging Problems with Minor Meloidogyne Species}

\begin{abstract}
Axel A. Elling
Department of Plant Pathology, Washington State University, Pullman 99164.

Accepted for publication 11 June 2013.

ABSTRACT

Elling, A. A. 2013. Major emerging problems with minor Meloidogyne species. Phytopathology 103:1092-1102.

Root-knot nematodes (Meloidogyne spp.) represent one of the most polyphagous genera of plant-parasitic nematodes. To date, close to 100 valid species are recognized. In contrast to the size of the genus, the majority of past research focused on a small number of species, i.e., the so-called 'major' species $M$. arenaria, M. hapla, M. incognita, and $M$. javanica. This review highlights recent work aimed at 'minor' root-knot nematodes: M. chitwoodi, M. fallax, M. minor, M. enterolobii (=M. mayaguensis), M. exigua, and M. paranaensis. Some of these species have been described only recently. After a brief profile of each species, identification methods and their application in Meloidogyne spp. are summarized. Intraspecific variation and its impact on plant resistance breeding are discussed and interactions between M. enterolobii and Fusarium solani are highlighted as an example of synergistic interactions with other plant pathogens. Future research on Meloidogyne spp. is not only shaped by recent breakthroughs such as completing the genome sequences of $M$. hapla and M. incognita, but is also influenced by changes in agriculture. Taken together, the aim of this review is to draw attention to previously neglected and newly described Meloidogyne spp. that are developing into major problems for agriculture in tropical and temperate climates.
\end{abstract}

Additional keywords: high-resolution melting curve, loop-mediated isothermal amplification, polymerase chain reaction, quarantine.

\section{ARE 'MAJOR' MELOIDOGYNE SPECIES REALLY THE ONLY ONES THAT MATTER?}

Root-knot nematodes (Meloidogyne spp.) represent one of the most polyphagous and damaging genera of plant-parasitic nematodes. Meloidogyne are biotrophic endoparasites that are able to infect virtually any species of higher plant and have a near cosmopolitan distribution. On a global scale, annual economic losses due to nematode infection of crops have been estimated at $\$ 173$ billion, with $\$ 13$ billion in the United States (2013 U.S. dollar figures based on an earlier comprehensive survey [96]). Given that Meloidogyne species have been reported as the most important genus of plant-parasitic nematodes worldwide (96), it seems realistic to estimate the annual economic losses at several billion U.S. dollars due to Meloidogyne alone. Even though approximately 100 nominal Meloidogyne species are known to date $(58,84,115)$, the vast majority of research has focused on just four species that have commonly been referred to as 'major' species: $M$. arenaria, $M$. hapla, $M$. incognita, and $M$. javanica. The reason

Corresponding author: A. A. Elling; E-mail address: elling@wsu.edu

http://dx.doi.org/10.1094/PHYTO-01-13-0019-RVW

(C) 2013 The American Phytopathological Society for the elevated status of these four species is partly due to the fact that they are extremely widespread and infect a wide range of principal crops, but to a certain degree it is also historical and can be traced back to a frequently cited study by Taylor et al. (100). In that study, the authors reported that $M$. arenaria, M. hapla, M. incognita, and $M$. javanica made up $99 \%$ of all species identified in over 660 isolates from 65 countries. Moens et al. (67) recently pointed out that the study by Taylor et al. (100) had several biases that may have skewed the data. For example, less than $6 \%$ of all samples were from temperate regions with temperatures of $5^{\circ} \mathrm{C}$ or less and a third of all samples came from just four crops. The widespread presence of $M$. arenaria, M. hapla, M. incognita, and $M$. javanica might also have led to frequent misidentifications of other species as one of the so-called 'major' species (67). It is also possible that less precise identification techniques or unawareness among nematologists led to more frequent errors in diagnoses in the past. Given the fact that none of the 'major' species is currently listed as a quarantine pathogen but that several other Meloidogyne species are, and that a number of studies have clearly demonstrated the enormous impact a number of formerly largely ignored Meloidogyne species can have, it seems questionable whether the historic classification into 'major' and 'minor' root-knot nematode species is still justifiable or whether it should be abandoned in favor of a broader and more inclusive thinking. The objective of 
this paper is to review and highlight recent research on $M$. chitwoodi, $M$. enterolobii, $M$. exigua, $M$. fallax, $M$. minor, and $M$. paranaensis. These species were selected because they are emerging as major problems for agriculture, especially in the light of changes in production trends, trade patterns, and climate. Future directions for work on root-knot nematodes are discussed.

\section{MELOIDOGYNE INFECTION STRATEGY}

Meloidogyne spp. are obligate parasites that infect underground plant organs. The mature female deposits eggs into an egg sac, which is made up of a gelatinous matrix produced by its rectal glands (12). Inside the egg, embryogenesis leads to the development of first-stage juveniles, which molt and develop into secondstage juveniles (J2). Under favorable conditions, which are mainly dictated by moisture and temperature, $\mathrm{J} 2$ hatch and locate host plants (43). $\mathrm{J} 2$ invade roots at the cell elongation region or sites of root branching and migrate intercellularly through the cortex. When they have reached the endodermis, which represents an impenetrable barrier for $\mathrm{J} 2$, they first migrate towards the root tip until they reach the meristematic region and then move back up into the vascular cylinder. Ultimately, the $\mathrm{J} 2$ become sedentary and induce profound changes in the host tissue (116). In compatible hosts, about half a dozen plant cells are transformed into giant cells (Fig. 1), which make up the nematode's feeding site and sole source of nutrition for the rest of its life cycle (reviewed by Perry et al. [84]). A typical symptom of Meloidogyne infection is the formation of galls at nematode feeding sites (Fig. 2). The exact mechanisms that lead to the establishment and maintenance of giant cells remain unclear, but it is very likely that effectors produced in the nematode's esophageal gland cells play a key role in the process (46). After the feeding site has been established, J2 increase in size and undergo subsequent molts into third- and fourth-stage juveniles ( $\mathrm{J} 3$ and $\mathrm{J} 4$ ), and after a fourth and final molt into adult females or males. Adult males regain their motility and are able to leave the root, whereas females remain sedentary. Males are not formed in all species and reproduction can occur parthenogenetically.

\section{SPECIES PROFILES}

This review focuses on six Meloidogyne species: $M$. chitwoodi, M. enterolobii, M. exigua, M. fallax, M. minor, and M. paranaensis. These species have not been chosen based on phylogenetic relationships or geographic distribution, but because they are perceived as emerging species that have the potential to cause significant damage to agriculture, especially in the light of changes in global trade patterns and production systems $(84,115)$. Whereas M. chitwoodi, M. fallax, and $M$. minor are temperate species, M. enterolobii, M. exigua, and M. paranaensis are mainly found in subtropical and tropical regions. In contrast to $M$. arenaria, $M$. hapla, $M$. incognita, and $M$. javanica, which generally cause large galls in roots, some of the species discussed here only cause very small galls ( $M$. chitwoodi and $M$. fallax) or hardly any galls (M. paranaensis). Therefore, some Meloidogyne spp. may go undetected if typical root-knot galls are expected as primary symptom.

M. chitwoodi. First described from potatoes originating from Washington (39), the Columbia root-knot nematode $M$. chitwoodi has emerged as a major problem for sustainable crop production in regions with a temperate climate. In the United States, $M$. chitwoodi is widespread throughout the Pacific Northwest and most western states. It is also found in Mexico, Argentina, several countries in continental Europe, Turkey and South Africa (5,38, 82 ). It infects a broad range of plants, including potatoes, vegetables, wheat, corn, alfalfa, and numerous weeds $(29,80,92) . M$. chitwoodi can also use various Brassica spp. as host, but considerable variability in pathogen aggressiveness exists (107). The ability of $M$. chitwoodi to reproduce on both monocotyledons and dicotyledons limits feasible crop rotation strategies as control measure (35). M. chitwoodi is a major problem for potato growers and requires control measures in virtually every field where it is found (53). It is able to reproduce on both potato roots and tubers, which facilitates its spread to previously uninfested areas with seed tubers. In potato tubers, almost all (96\%) of the nematodes are found in the outermost $5.25 \mathrm{~mm}$ of the tuber, which corresponds to the vascular ring (112). M. chitwoodi symptoms include
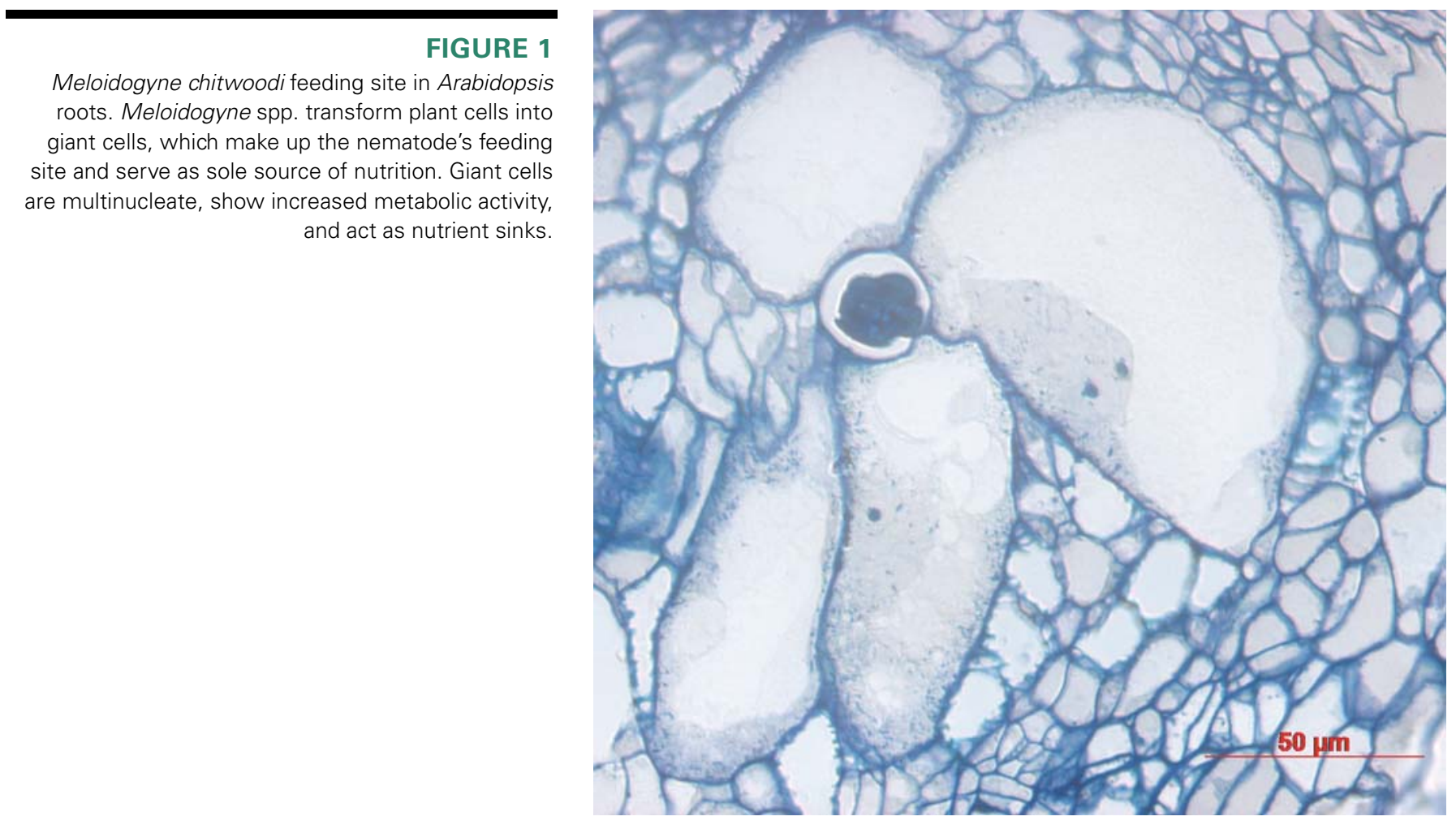

Vol. 103, No. 11, 2013 
stunting and yellowing above-ground and small galls on roots and tubers without secondary roots emerging from them (5). Some of the damage potential of $M$. chitwoodi can be attributed to the ability of $\mathrm{J} 2$ to hatch at relatively low $\left(6^{\circ} \mathrm{C}\right)$ temperatures (25). In fact, Ingham et al. (54) estimated that as little as one juvenile per $250 \mathrm{~g}$ of soil in potato fields at the beginning of the growing season can lead to a total yield loss due to quality defects if no control measures are taken. Vertical distribution of $M$. chitwoodi in the field is not influenced by poor, moderate, or good hosts in the rotation but is a function of soil properties (113). To limit future spread of this nematode, regulatory agencies in many countries have designated $M$. chitwoodi as quarantine pathogen, which limits trade of infested shipments and further underscores the impact this nematode has on agriculture.

M. enterolobii. Originally found on roots of pacara earpod trees (Enterolobium contortisiliquum) on Hainan Island in China (117), much confusion has surrounded this nematode over the years. Whereas it was previously misidentified as $M$. incognita, an indepth morphological analysis led to its recognition as a new species (117). A couple of years after the description of $M$. enterolobii, a new species of root-knot nematode was described that resembled $M$. enterolobii but seemed to differ from it in certain morphological features. That species was first found on eggplant in Puerto Rico and was named M. mayaguensis (88). Since then, a significant amount of molecular and morphological data have accumulated that questioned the taxonomic relationship of $M$. enterolobii and M. mayaguensis (22). Today, it is generally accepted that $M$. enterolobii and $M$. mayaguensis are one and the same species, with M. mayaguensis being the junior synonym (60). Following this convention, in this article studies based on M. mayaguensis will be referred to as $M$. enterolobii. In its original description, the common name pacara earpod tree root-knot nematode has been suggested (117). M. enterolobii has been found in several African countries, China, Vietnam, Florida, Central and South America, France, and Switzerland (6). Whereas M. enterolobii was initially thought to be restricted to tropical areas, recent reports show that this is not the case. In fact, its establishment in the Mediterranean region and other subtropical areas seems likely (22) and a number of countries and regulatory agencies have designated M. enterolobii as quarantine pathogen. $M$. enterolobii has an exceptionally wide host range comparable to that of $M$. incognita and includes many vegetables, guava, acerola, ornamentals, and weeds $(51,92$, 117). Above-ground symptoms include yellowing and stunting, whereas below ground relatively large galls can be found (6).
Plant-parasitic nematodes are part of a complex ecosystem in the rhizosphere that includes other plant pathogens. However, interactions between the Meloidogyne spp. discussed here and other plant pathogens have barely been studied. A remarkable exception to this is guava decline. In Brazil, M. enterolobii has become the number one disease in guava and has been estimated to infest over 5,000 ha or about a third of the guava production area (83). Since parasitized guava trees develop rotten roots in later stages of the disease, the involvement of a soilborne pathogen that interacts with $M$. enterolobii was suspected (42). Extensive analyses of infected root fragments led to the identification of Fusarium solani $(41,42)$. Further experiments clearly showed that $M$. enterolobii and $F$. solani have a synergistic effect on disease development. Whereas $M$. enterolobii alone was able to induce galling and a limited amount of root rot, F. solani did not cause root rot when in isolation. When combined, nematode and fungus led to drastic root rot and typical guava decline symptoms, which suggests that guava decline is a disease complex between $M$. enterolobii and $F$. solani $(41,42)$.

M. exigua. First described in 1887 (40), M. exigua is emerging as a significant problem for tropical agriculture. M. exigua is widely distributed throughout Central and South America, India, China, and is also found in some southern European countries. Among the 17 Meloidogyne spp. that are currently known to infect coffee, $M$. exigua is one of the most damaging species (98). Other hosts include tomato, onion, sugarcane, banana, citrus, rice, rubber tree, and weeds (e.g., Taraxacum officinale, Amaranthus deflexus, and Poinsetta heterophylla [92]). M. exigua generally causes severe root galling in coffee and other plants, as well as stunting and yellowing (84). In Costa Rica and Brazil, two of the leading coffee-producing countries, yield losses in coffee plantations of 10 to $20 \%$ and $45 \%$, respectively, have been attributed to this nematode $(8,11)$. A survey showed that $M$. exigua is present in $22 \%$ of the coffee plantations and $95 \%$ of the districts in southern Minas Gerais State in Brazil, a region that accounts for nearly half of the total coffee acreage in that country (24). The widespread distribution of M. exigua in Latin America is a major problem for the coffee industry, because all of the main coffee cultivars grown are susceptible to this nematode and germplasm screens failed to identify resistant accessions in Coffea arabica (7). A recent study showed that the lipid reserves of $M$. exigua correlate with temperature, rainfall, and nematode population density and that in Minas Gerais, the best time to implement chemical control measures against $M$. exigua is November, which

\section{FIGURE 2}

Typical root-knot nematode symptoms on tomato roots. Infection with Meloidogyne spp. led to massive galls in areas where feeding sites developed. This has a negative effect on normal root growth and the plant's ability to take up nutrients and water.

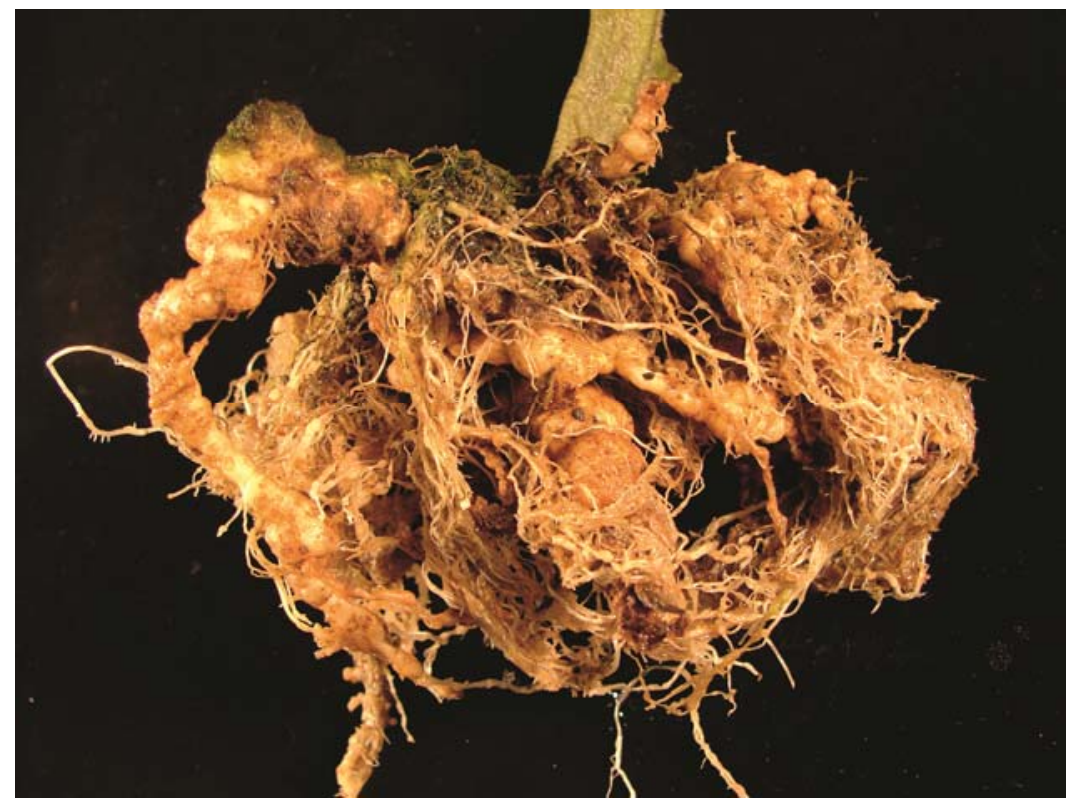


coincides with renewed root growth, a high level of lipid reserves in J2, high nematode population density, and high infectivity (94).

M. fallax. Initially thought to be a new race of $M$. chitwoodi from the Netherlands (110), M. fallax was subsequently described as a species in its own right (57). It has emerged as a major problem for temperate agriculture. M. fallax, a quarantine pest, has been detected in Europe, South Africa, Australia, New Zealand, and most recently, in the United States $(5,75)$. Its host range, at least for major agronomic crops, is similar to that of $M$. chitwoodi and includes a range of vegetables (e.g., tomato and carrot) and monocotyledons such as wheat and barley (29). However, its most important agronomic host is potato, in which it can lead to total yield losses due to quality defects and quarantine issues $(3,5)$. M. fallax symptoms are very similar to those of $M$. chitwoodi. Both species incite small galls, typically without secondary roots, and can lead to stunting and yellowing aboveground. In potato tubers, they cause numerous small pimple-like swellings (5). M. fallax is considered as closely related to $M$. chitwoodi $(47,109)$, with which it can hybridize and produce viable F1 progeny under greenhouse conditions (105). In spite of their close genetic relationships, there are interesting differences in the biology of $M$. chitwoodi and $M$. fallax that may have an impact on control strategies. For example, Wesemael et al. (114) showed that there is a distinct difference in hatching response in $M$. chitwoodi and M. fallax. Whereas M. fallax $\mathrm{J} 2$ did not depend on root diffusates to hatch, $M$. chitwoodi underwent obligate quiescence: egg masses produced towards the end of the growing season contained a significant percentage of $\mathrm{J} 2$ that required host diffusates to hatch (114). Moreover, plant age did not affect production of eggs per egg mass in M. fallax, but senescing plants reduced eggs per egg mass in the related $M$. chitwoodi. In other words, whereas $M$. chitwoodi seems to survive in the absence of a host by producing quiescent $\mathrm{J} 2$ that require a host stimulus to hatch, the survival strategy of $M$. fallax presumably relies more on the ability of hatched $\mathrm{J} 2$ to survive in the soil. Consequently, $M$. fallax $\mathrm{J} 2$ are immediately able to penetrate host roots once they emerge, which could represent an evolutionary advantage in areas where $M$. chitwoodi and M. fallax co-occur (114).

M. minor. Described less than a decade ago, M. minor is causing increasing concern in temperate agriculture and horticulture. Initially identified from a potato field in the Netherlands that used to be a pasture (59), M. minor has been found primarily on golf courses and sports grounds in the Netherlands, Belgium, United Kingdom, and Ireland, on which it tends to cause yellow-patch disease within a few years after new greens have been established $(4,59,111)$. It has also been found in coastal dunes and there is concern that it is spreading throughout northwest Europe (104). Most recently, M. minor has been found on a golf course in Washington, which marks its first documented detection in the western hemisphere (66). It is unknown why $M$. minor has gone undetected for such a long time but now appears to be spreading to new areas. Turner and Fleming (104) speculated that the increased use of creeping bentgrass on putting greens, an excellent host for M. minor, the introduction of sand from coastal sites, or a decrease of urea-based fertilizers on golf courses, which may act antagonistically on nematode development might all have led to the current increase in reports of $M$. minor. Furthermore, the increasing popularity of instant lawn, a process in which grass sods are mechanically cut, rolled and installed rather than planted by seed could play a role in distributing Meloidogyne spp. that infect grasses, including $M$. minor. Since $M$. minor can easily be transmitted by footwear and sports equipment, adequate control measures seem challenging at this time (84). There are indications that M. minor could develop into a serious problem for agronomic crops when moving from grasses to arable land (104), even though recent studies provide conflicting results and a better risk assessment is needed $(59,101)$. M. minor is known to reproduce on carrots, alfalfa, oat, lettuce, and tomato under greenhouse conditions (59). Under field conditions, $M$. minor failed to reproduce on sugar beet, maize, and rye (101). Importantly, $M$. minor reproduces on potato roots and tubers under field conditions, which could facilitate its spread to new areas (101). Symptoms are very similar to those of $M$. chitwoodi and $M$. fallax, i.e., small galls in roots and pimple-like swellings on the surface of potato tubers (59). M. minor did neither reduce tuber yield nor quality in two potato cultivars in the Netherlands, but it is impossible to predict its impact on potato cultivars grown elsewhere at this time (101). Before conclusions about the ability of M. minor to create problems in potatoes or other agronomic crops can be drawn, more studies about its biology are needed. To address some of these issues, Morris et al. (70) examined the effect of temperature on $M$. minor hatch and $\mathrm{J} 2$ activity and found that eggs collected from fields at all times of the year hatched at $20^{\circ} \mathrm{C}$, which might indicate that $M$. minor does not undergo a diapause. Given its ability to move from grasses to major agronomic crops, it seems prudent to assume that $M$. minor could become a significant problem for temperate agriculture. To account for its damage potential and risk of spread, the European and Mediterranean Plant Protection Organisation (EPPO) moved $M$. minor on its alert list (4).

M. paranaensis. Commonly known as Paraná coffee root-knot nematode, this species is another example of a 'minor' root-knot nematode whose taxonomic position was unclear for a long period of time. For over 20 years, $M$. paranaensis was thought to be $M$. incognita (20). In 1996, an in-depth morphological and molecular analysis ended this confusion and established M. paranaensis as a new species (20). In fact, to the uninitiated eye, $M$. paranaensis might go undetected altogether. In coffee, this species does not cause typical root-knot nematode galls under field conditions. Instead, M. paranaensis infection leads to cracked cortical tissue on the taproot and necrotic spots along the roots, together with unspecific above-ground symptoms such as chlorosis and leaf drop or plant death (20). M. paranaensis is currently only reported in Brazil and Guatemala. Hosts include tobacco, watermelon, tomato, soybean, and weeds, whereas cotton, pepper, peanut, oats, corn, and a number of grasses proved to be nonhosts for $M$. paranaensis $(19,20,68,69)$. Its main host, however, is coffee, where it is considered as one of the most destructive rootknot nematode species (98).

\section{IDENTIFICATION METHODS - OLD AND NEW}

Morphology and isozymes. Adequate nematode control requires proper species identification to diagnose the problem, especially in the case of quarantine pests. However, the examples of $M$. fallax, which was thought to be $M$. chitwoodi, and $M$. paranaensis and $M$. enterolobii, both of which were thought to be $M$. incognita as detailed above clearly show that much work still needs to be done when it comes to species identification in Meloidogyne. The classic techniques to confirm the identity of a Meloidogyne species are based on morphology and include analyzing perineal patterns and other morphological features (Fig. 3). However, this requires significant expertise that is often lacking today. Nevertheless, morphology will remain an integral part to species identification in the future. Another routine technique for nematologists working on Meloidogyne is isozyme analysis, especially of esterases and malate dehydrogenase (33). Even though this technique is less important for species identification of other plant pathogens today, it remains relevant for Meloidogyne and has advantages over more modern techniques like polymerase chain reaction (PCR). For example, isozyme analysis does not require a priori knowledge about the sample (i.e., no primers) and allows for species identification with considerably less expensive equipment. On the other hand, isozyme analysis is done on 
females and does not work with single $\mathrm{J} 2$, the life stage that is found most often in soil samples. Perineal patterns and isozyme patterns are known for all Meloidogyne species discussed here and remain valuable tools for species identification.

Species-specific PCR. A number of studies have led to the development of species-specific PCR primers for $M$. chitwoodi (14), M. enterolobii (14,102), M. exigua (89), M. fallax (14), $M$. minor (28), and M. paranaensis (89). Additionally, for M. minor, a real-time PCR assay has recently been developed (28). Adam et al. (2) combined previously created PCR primers and protocols into a highly useful molecular key that enables PCR-based differentiation of seven Meloidogyne spp., including M. chitwoodi, $M$. enterolobii, and M. fallax. It would be desirable to develop a more extensive molecular key including more species and update it with newly developed species-specific primers. A large-scale application of PCR-based species identification has been reported by Powers et al. (87), who conducted a survey of Meloidogyne spp. in potato fields in the central United States. Using both mitochondrial and $18 \mathrm{~S}$ ribosomal markers, they found that the mitochondrial gene region provided better species discrimination and allowed for resolution of intraspecific variability (87).

Randig et al. (90) recently identified and characterized a novel satellite DNA family, named pMmPet, in M. enterolobii. Using 44 $M$. enterolobii isolates and 15 root-knot nematode species, the authors showed that pMmPet-based sequences can be used for species-specific identification of $M$. enterolobii by PCR, Southern blots, and dot blots (90). This not only increases the tool kit for identifying this quarantine pest but also sheds more light on the genome differences between Meloidogyne spp.

Current efforts are aimed at developing multiplex and real-time PCR protocols for Meloidogyne. For example, Zijlstra and van Hoof (118) reported on a TaqMan assay for the simultaneous detection of both $M$. chitwoodi and M. fallax from purified DNA and infected plant material. Similarly, Hu et al. (49) developed a one-step multiplex PCR for simultaneous detection of M. entero- lobii, M. incognita, and M. javanica using DNA from galls instead of pure nematode tissue. This further facilitates species identification and circumvents tedious and time-consuming nematode extraction steps. Additionally, a DNA oligonucleotide microarray has been developed that allows for detection of $M$. chitwoodi in pure and mixed samples that lends itself to high throughput diagnostic screening (36). Unfortunately, high throughput screens have not been developed yet for most species, which hampers their widespread use. Recent advances in next-generation sequencing coupled with barcoding have enabled significant advances in nematode biodiversity estimation and ecometagenetics $(85,86)$, and if adapted to management problems, could provide a promising alternative to PCR or microarray-based high throughput screening approaches.

High-resolution melting curve. Depending on the application, nematode samples may have to be analyzed as quickly as possible, for example if regulated species are suspected in a shipment. Conventional PCR protocols can take several hours to complete after which the products need to be separated on an agarose gel to be visualized and interpreted. High-resolution melting curve (HRMC) analysis is a new technique that has the potential to significantly reduce PCR analysis time by eliminating the agarose gel step (91). HRMC exploits the melting behavior of PCR products upon heat denaturation using a modified real-time PCR machine (91). The main advantages of HRMC are that it is highly sensitive, avoids further need to handle or process the PCR product and saves a significant amount of time. Holterman et al. (48) recently adopted HRMC to develop a protocol to differentiate M. chitwoodi, M. fallax, and M. hapla from each other and from $M$. arenaria, $M$. incognita, and $M$. javanica. Work to optimize HRMC for M. enterolobii is ongoing (48).

Loop-mediated isothermal amplification. A disadvantage of PCR protocols is that they require costly thermal cyclers, relatively pure template DNA and can take several hours until results can be analyzed. A new technique, loop-mediated isothermal
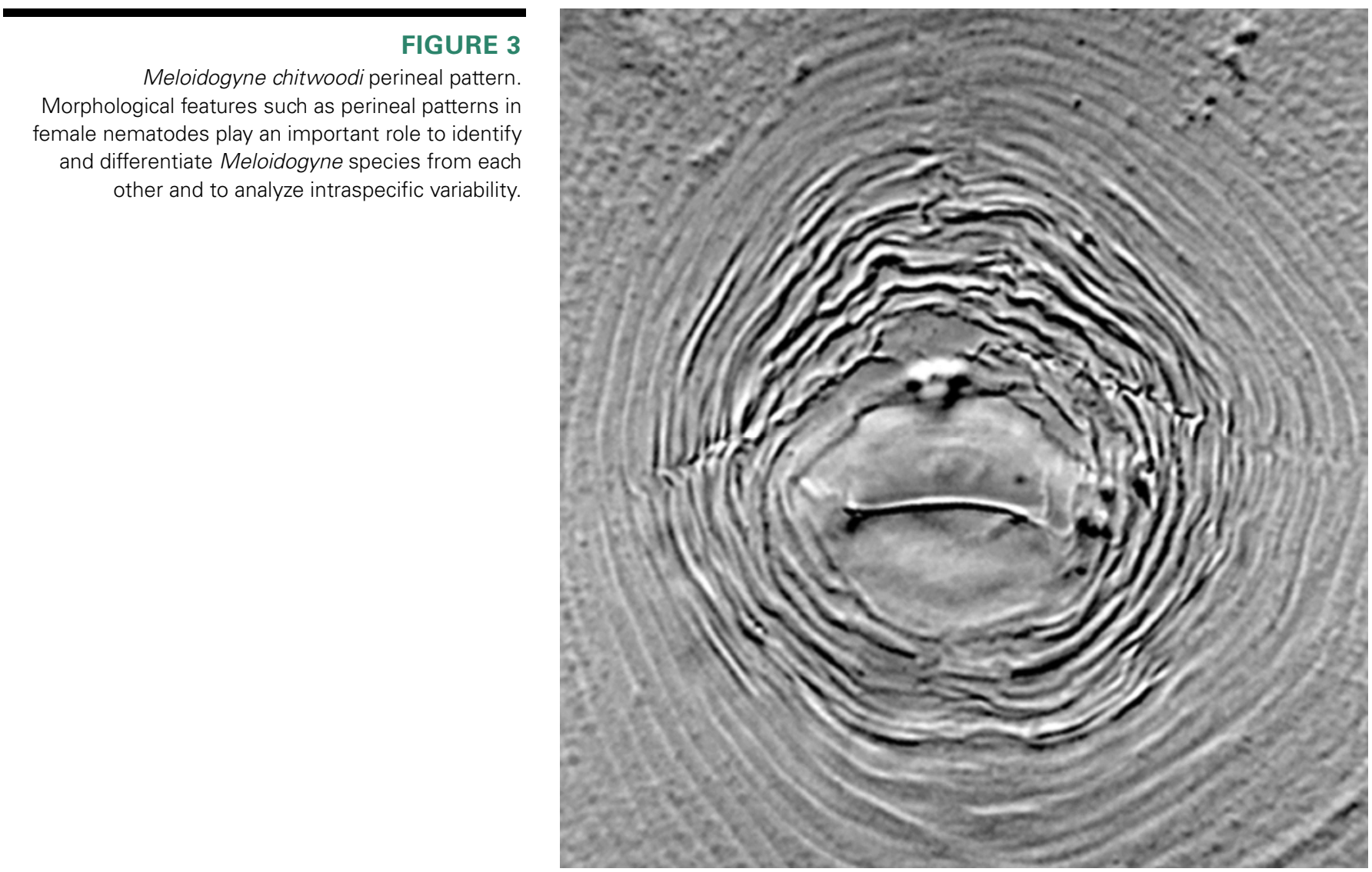
amplification (LAMP) circumvents all these problems and is currently making its entry into nematode diagnostics. LAMP is based on a DNA polymerase with strand-displacement activity and four to six primers that bind to six or eight regions of the target DNA (103). Some of the main advantages of LAMP over conventional PCR are that it can be conducted in a simple heatblock or waterbath at a constant temperature and only takes 30 to $60 \mathrm{~min}$ to complete. LAMP products can be visualized with the naked eye by adding DNA-intercalating dyes or metal-ion indicators. Niu et al. developed LAMP assays to identify $M$. arenaria, $M$. hapla, $M$. incognita, and $M$. javanica (76), and most recently $M$. enterolobii (77). LAMP could prove to be a valuable tool, especially when samples need to be identified in the field or if rapid identification is paramount. It is to be expected that LAMP assays will be developed for many more Meloidogyne spp. and other nematodes over the next couple of years and will become a routine technique.

It cannot be overemphasized that correct species identification is imperative if proper control and quarantine measures are to be taken. Given the recent decline in the number of nematologists trained in classic morphology and taxonomy (described below), molecular identification tools will become more important in the future. However, with a sole reliance on molecular tools, the risk of false positives (or negatives) increases. In a recent study, species-specific primers that were developed for M. fallax were found to cross-react with DNA from $M$. minor, resulting in the same amplicon size for both species (75). The M. fallax primers that were used in that study were developed before $M$. minor was described. Given that M. fallax is a highly regulated quarantine pest and that $M$. fallax and $M$. minor are both temperate species that can co-occur, this example shows that false identifications can have an enormous economic impact. To avoid future problems, it would be desirable if existing molecular keys $(2,87)$ were updated and a wide range of recently described Meloidogyne spp. and populations were incorporated. Ideally, such keys would not only include species-specific PCR primers, but also take full advantage of novel molecular tools, such as TaqMan, HRMC, and LAMP assays to increase the robustness of molecular diagnosis strategies.

\section{INTRASPECIFIC VARIATION}

Even though overall morphological and molecular characteristics enable the identification of Meloidogyne species, intraspecific variability is an important aspect of nematode biology that needs to be taken into account to avoid misidentifications and to optimize management strategies. For Meloidogyne, host races are considered intraspecific variants that can be separated by their ability to reproduce on a set of host plants from different genera. In contrast, pathotypes are populations that reproduce on a specific plant species that is resistant to other populations of the same Meloidogyne species (32). However, this nomenclature can be confusing and is not always used consistently by nematologists. Roberts (93) attempted to solve these problems by introducing a biotype system that could replace the race and pathotype classification. The goal here is not to give a comprehensive overview of intraspecific variability in Meloidogyne but to highlight some of the research that has recently been conducted in this area and relates to the species discussed in this review.

M. chitwoodi is a variable species and it has long been known that two races can be distinguished based on their ability to infect carrots or alfalfa (18). While neither race is able to infect Solanum bulbocastanum clone 22, two pathotypes, one of which was identified only a few years ago, are able to do so (18). However, studies in the Netherlands found deviations from expected race and pathotype behavior on differential hosts $(106,108)$, which could have important consequences for resistance breeding. Most recently, Humphreys-Pereira and Elling (52) showed that even though ribosomal DNA and isozyme phenotypes were conserved across various $M$. chitwoodi isolates, which is important for diagnosis of this quarantine pathogen, $M$. chitwoodi shows a high degree of mitochondrial heteroplasmy. Furthermore, M. chitwoodi isolates tested showed low genetic structure, which could be the result of an exchange of genetic material between populations. If so, this could explain some of the aberrant race and pathotype behavior observed previously $(106,108)$ and affect resistance breeding. In-depth morphological analyses of $M$. chitwoodi secondstage juveniles and males from different isolates are ongoing (D. A. Humphreys-Pereira and A. A. Elling, unpublished data).

In contrast to $M$. chitwoodi, for which several recent studies $(30,34,52,87)$ showed a high degree of molecular variability, $M$. enterolobii seems to be more genetically homogeneous. Tigano et al. (102) used three different neutral molecular markers, amplified fragment length polymorphism, inter-simple sequence repeat, and random amplified polymorphic DNA (RAPD), and tested 16 $M$. enterolobii isolates from different geographic areas and hosts. They found that all three markers indicated a high level of homogeneity. Similar to $M$. enterolobii, M. paranaensis appears to be a genetically homogeneous species. Using RAPD markers, two independent studies found a low level of variability between different isolates $(21,89)$. Nevertheless, distinct host races may exist also in $M$. paranaensis and need further characterization (95).

Studies related to genetic diversity in $M$. exigua have given contradicting results and demonstrate the need for more in-depth analyses. Whereas Randig et al. (89) found high infraspecific variability in $M$. exigua when using RAPD markers, Carneiro et al. (21) reported low levels of polymorphisms in $M$. exigua using the same technique. Importantly, intraspecific variability can also change the host range, as mentioned above for $M$. chitwoodi. In $M$. exigua, a race exists that infects only rubber trees, inflicting massive damage to this industry. Two recent studies $(72,73)$ aimed at further characterizing this unique variant and attempted to determine molecular and morphological differences to the other $M$. exigua races that parasitize coffee. Importantly, whereas SCAR markers were not able to distinguish $M$. exigua races from coffee and rubber tree, the authors found an additional band in the esterase phenotype of the rubber tree isolates when using isozyme analysis (72).

\section{RESISTANCE BREEDING}

Resistant germplasm is the most sustainable and economic management strategy to control plant-parasitic nematodes. However, a wide host range of Meloidogyne spp. in general, intraspecific nematode variants that overcome resistance genes and difficulties in identifying resistance genes in plants hamper progress in this area. Additionally, the well-studied $M i$ resistance gene from tomato proved ineffective against $M$. enterolobii (61) and M. exigua (97).

Past work identified $R_{M c(b l b)}$, a resistance gene in Solanum bulbocastanum, which is effective against $M$. chitwoodi and has been introgressed into cultivated potato (17). Unfortunately, $M$. chitwoodi pathotypes that are able to overcome this resistance under field conditions are known (18). Fortunately, further investigation showed that one potato breeding line possessed tuber resistance against all $M$. chitwoodi races and pathotypes tested and that there are actually two dominant monogenes that control $M$. chitwoodi resistance $(16,18)$. Recently, partial resistance against $M$. chitwoodi was found in the Netherlands in new potato genotypes (79). S. sisymbriifolium could act as yet another source of resistance against $M$. chitwoodi (31). A wild potato species, $S$. sparsipilum, was also the source of resistance against the related M. fallax (62). It was shown that even though M. fallax $\mathrm{J} 2$ were 
able to invade $S$. sparsipilum roots and induce giant cell formation, subsequent massive necrosis of surrounding parenchymatous vascular cylinder cells led to the degeneration of the feeding site and stopped nematode development (63).

Significant effort has also been put into finding resistance against $M$. exigua in coffee. Whereas no resistant accessions have yet been identified in $C$. arabica, a high level of resistance is known from $C$. canephora and C. racemosa (98). Interestingly, $C$. arabica does seem to carry resistance against $M$. paranaensis (15). An M. exigua resistance gene, Mex-1, was identified in $C$. canephora and is now widely used in $M$. exigua-resistant coffee cultivars (78). The resistance mechanism of Mex-1 seems to rely on a hypersensitive response, which significantly reduces M. exigua invasion and development (7). Metabolic profiling of resistant and susceptible coffee cultivars infected with $M$. exigua showed dramatic differences in fumaric, formic, and quinic acid when resistant and susceptible plants were compared, with higher levels found at earlier timepoints in resistant plants. Additionally, sucrose concentrations increased almost fourfold soon after $M$. exigua infection in resistant plants, but did not change in susceptible cultivars. In contrast, the concentration of alkaloids was much higher in susceptible compared with resistant plants upon nematode infection (65). However, there are indications that $M$. exigua is able to overcome resistant coffee germplasm. For example, Muniz et al. (74) found a natural M. exigua population in Rio de Janeiro State in Brazil that is able to break the Mex-1 resistance under greenhouse conditions. Moreover, a 5-year field assessment of susceptible and resistant coffee cultivars in the same state showed that $M$. exigua can drastically reduce the vegetative development and productivity of coffee cultivars regardless of their resistance status, which casts doubt on the durability of Mex-1 (9).

\section{WHAT CAN WE LEARN FROM ‘MAJOR’ SPECIES?}

Without a doubt, $M$. incognita has made major contributions to our understanding of root-knot nematodes and if the number of $M$. incognita publications is any guide, $M$. incognita seems to have taken the place of a model species for the entire genus. While studying $M$. incognita has brought about invaluable advances in our knowledge of the genus as a whole, it should not be assumed that everything that is true for $M$. incognita is also true for M. chitwoodi, M. enterolobii, M. exigua, M. fallax, M. minor, or $M$. paranaensis. A case in point is the recent finding that the IGS2 region of the ribosomal DNA cistron enables the successful differentiation of $M$. arenaria, $M$. incognita, and $M$. javanica from M. chitwoodi, M. fallax, and M. hapla using HRMC analysis, but that this region is not suitable for M. enterolobii (48). Similarly, the $M i$ resistance gene was not as successful against $M$. enterolobii (61) and M. exigua (97) as hoped. Furthermore, chemical and alternative management strategies that are currently employed against $M$. incognita and other 'major' Meloidogyne spp. may need to be optimized for 'minor' species. For example, synthetic nematicides are not necessarily labeled for use against the Meloidogyne spp. discussed here and biocontrol agents such as Pasteuria spp. can be effective against some Meloidogyne spp. but not others (26). Thus, it would be desirable if considerably more effort were put into in-depth studies of individual Meloidogyne spp. and specific plant-Meloidogyne pathosystems to fully appreciate the peculiarities of root-knot nematode species other than M. incognita.

Recent breakthroughs in phytonematology include completing the genome sequences for $M$. incognita and M. hapla $(1,13$, 81). Remarkably, there are vast size differences between these genomes. Whereas $M$. hapla features with $54 \mathrm{Mb}$ the smallest metazoan genome known to date, the genome sequence of $M$. incognita is over $86 \mathrm{Mb}$. What does this mean for an average
Meloidogyne genome size? Can we expect that other Meloidogyne genomes are more like M. hapla or M. incognita? What does this tell us about the evolution of the genus? Sequencing of additional Meloidogyne genomes is ongoing and will soon provide answers to these questions and raise new ones. Genomic information about $M$. incognita is already being exploited to advance studies of other root-knot nematodes. For example, a genome-wide survey of microsatellites in $M$. incognita led to the identification of over 2,200 di- to hexanucleotide loci (23). In a related study (71), some $M$. incognita microsatellites were tested in other root-knot nematodes and showed cross-amplification in $M$. enterolobii, $M$. exigua, and $M$. paranaensis, but not in M. chitwoodi and M. fallax. This shows that even though a 1:1 transfer from $M$. incognita to other species is unrealistic, the infrastructure that exists for $M$. incognita can be used to speed up research on other Meloidogyne species.

RNA interference (RNAi) has become a powerful tool to downregulate gene activity and has also proven effective as a control tactic against Meloidogyne. For example, Huang et al. (50) used plant-mediated RNAi to deactivate an effector gene in the nematode and showed that this approach can lead to broadspectrum resistance against $M$. arenaria, M. hapla, M. incognita, and $M$. javanica. Lilley et al. (64) recently summarized the latest advances in the use of RNAi against phytonematodes. Whereas this technique is still in its infancy for Meloidogyne, a vast amount of RNAi data exists for the model nematode Caenorhabditis elegans. A recent study aimed at identifying genes in a number of Meloidogyne spp. that are conserved in C. elegans and are known to lead to a lethal phenotype when deactivated by RNAi in that nematode. An accompanying database has been built and can be accessed by interested researchers (55).

\section{THE IMPACT OF CHANGES IN AGRICULTURE}

Modern agriculture is undergoing changes that can have a significant impact on the distribution and control of Meloidogyne spp. and other plant-parasitic nematodes. For example, recent years have seen the phase-out of formerly widely used fumigants such as methyl bromide and a number of nonfumigant nematicides are relatively old products that are faced with increasing regulations due to environmental concerns. Even though individual regulations differ from country to country, the overall trend is going towards fewer available synthetic nematicides. Does this mean we have to expect an increase in Meloidogyne problems? Answering this question is difficult and mostly speculation, but a recent survey of growers in Spain indicates that the answer could be yes. In face-to-face interviews of 120 farm advisers, average yield losses due to Meloidogyne spp. were estimated at over $30 \%$ for horticultural crops. Over $38 \%$ of the farm advisers believed that Meloidogyne infections had increased over the past 5 years (99). If a reduction of nematicides increases Meloidogyne problems, organic production methods should be able to serve as an indicator. Converting formerly conventionally used farmland to organic production methods is known to increase soil nematode density. Plant-feeding nematode densities can increase due to the constant presence of cover crops and more weeds (27). In a systematic comparison of fields under conventional or organic production in Germany, Hallmann et al. (45) found that Meloidogyne spp. were present in about half of the surveyed fields, regardless of production system. Grower surveys in the same study showed that nematode problems generally started 5 to 10 years after fields had been converted to organic methods. Forty percent of growers surveyed in that study first became aware of nematode problems over 10 years after changing to organic production methods, which led the authors to speculate that organic production methods might have created nematode problems in the long term (45). Furthermore, it is possible that an increase in specialization of 
organic growers could increase Meloidogyne problems in the future.

In addition to changing production trends, new trade patterns can have profound consequences on problems with Meloidogyne and other plant-parasitic nematodes in the future. In two relatively recent large-scale nematode surveys in Italy and Spain, respectively, the trade of uncertified ornamentals was raised as one of the main concerns of how previously undetected plant-parasitic nematode species might get introduced to new areas $(10,44)$. Not only plant wholesalers, but also individual consumers and hobby gardeners can have a massive impact in this regard. The internet provides ample opportunities to purchase exotic plants, complete with their exotic plant-parasitic nematodes and other pathogens. Out of 170 orders placed with international vendors on the internet in 2012, $89 \%$ did not comply with phytosanitary import requirements in a study conducted by a national plant quarantine institute in Germany (56). While some vendors did not deliver plants and cited import restrictions, a disturbing 39\% of plant shipments were intentionally mislabeled as toys, books, or other innocuous items-presumably to avoid detection by customs during import. Consignments included soil and high-risk plant material such as potato seed tubers, Citrus sp., and Pinus sp.-all of which are known to harbor plant-parasitic nematodes that are listed as quarantine pathogens. Pathogens were found in $13 \%$ of the consignments and $2 \%$ were quarantine pests, including Meloidogyne sp.

In addition to changes in production systems and trade patterns, a third major trend that has an impact on nematode problems is the steady decrease of trained nematologists. Nematode problems are oftentimes easy to overlook or misdiagnose, and require specialized training to be identified and treated. In a recent study aimed at analyzing institutional and demographic trends in plant pathology in the United States, plant nematology was identified as one of only two subdisciplines that have undergone massive declines (37). In fact, if membership of the Society of Nematologists ( $\mathrm{SON}$ ) is taken as indicator, the situation is serious indeed: since a membership peak in 1987, the number of SON members has decreased by about $50 \%$, which most likely mirrors the research, extension and teaching situation at a state and university level in the United States (37). This trend will create immense problems for agriculture, especially if retiring faculty is not replaced and their respective specialty field dies out altogether. For example, the small number of trained nematode taxonomists who are not near retirement is alarming and of obvious importance for diagnosis and identification of potential quarantine species.

\section{CONCLUSIONS AND FUTURE PERSPECTIVES}

I began this review with a question: are 'major' Meloidogyne species really the only ones that matter? It is evident from the work discussed here that the answer should be an emphatic no. M. chitwoodi, M. enterolobii, M. exigua, M. fallax, M. minor, M. paranaensis, and a wide range of other Meloidogyne spp. that could not be discussed here due to space constraints are hugely important plant pathogens wherever they are found. In fact, depending on the area and the affected crop, 'major' species may play second fiddle compared with their lesser known cousins. So where does this leave us? In my opinion, the concept of 'major' and 'minor' Meloidogyne spp. is misleading and suggests that 'minor' species can be largely ignored and do not cause harm. Nothing could be further from the truth. It might be more useful to abandon this artificial classification scheme. After all, no other group of plant-parasitic nematodes is divided this sharply into 'major' and 'minor' species. It is hoped that future research focuses more on root-knot nematodes that have previously been largely ignored in favor of $M$. incognita and other seemingly more important 'major' species. The infrastructure and knowledge base that exist for $M$. incognita enables unprecedented research progress for other species and will open the door to exciting new questions. How do the genomes of $M$. chitwoodi, M. enterolobii, M. exigua, M. fallax, M. minor, and $M$. paranaensis compare to $M$. hapla and $M$. incognita? What can we learn about plantnematode interactions when we compare different species? Why do certain resistance genes work against some Meloidogyne spp. but not others? Given how little we still know about root-knot nematode biology, there is no shortage of work for plant nematologists. Who knows what surprises Meloidogyne still holds in store!

\section{ACKNOWLEDGMENTS}

I apologize to colleagues whose relevant publications could not be cited due to space constraints. Funding for work on Meloidogyne in my laboratory has been provided by USDA, Washington State Department of Agriculture, Washington State Potato Commission, and Idaho Potato Commission. I thank R. Ingham and two anonymous reviewers for critical reading of an earlier version of the manuscript. PPNS No. 0609, Department of Plant Pathology, College of Agricultural, Human, and Natural Resource Sciences, Agricultural Research Center, Project No. WNP00744, Washington State University, Pullman, WA 99164-6430.

\section{LITERATURE CITED}

1. Abad, P., Gouzy, J., Aury, J. M., Castagnone-Sereno, P., Danchin, E. G., Deleury, E., Perfus-Barbeoch, L., Anthouard, V., Artiguenave, F., Blok, V. C., Caillaud, M. C., Coutinho, P. M., Dasilva, C., De Luca, F., Deau, F., Esquibet, M., Flutre, T., Goldstone, J. V., Hamamouch, N., Hewezi, T., Jaillon, O., Jubin, C., Leonetti, P., Magliano, M., Maier, T. R., Markov, G. V., McVeigh, P., Pesole, G., Poulain, J., Robinson-Rechavi, M., Sallet, E., Ségurens, B., Steinbach, D., Tytgat, T., Ugarte, E., van Ghelder, C., Veronico, P., Baum, T. J., Blaxter, M., Bleve-Zacheo, T., Davis, E. L., Ewbank, J. J., Favery, B., Grenier, E., Henrissat, B., Jones, J. T., Laudet, V., Maule, A. G., Quesneville, H., Rosso, M. N., Schiex, T., Smant, G., Weissenbach, J., and Wincker, P. 2008. Genome sequence of the metazoan plant-parasitic nematode Meloidogyne incognita. Nature Biotechnol. 26: 909-915

2. Adam, M. A. M., Phillips, M. S., and Blok, V. C. 2007. Molecular diagnostic key for identification of single juveniles of seven common and economically important species of root-knot nematode (Meloidogyne spp.). Plant Pathol. 56:190-197.

3. Anonymous. 2006. Meloidogyne chitwoodi and M. fallax: Sampling potato tubers for detection. EPPO Bull. 36:421-422.

4. Anonymous. 2006. Meloidogyne minor alert list. European and Mediterranean Plant Protection Organisation Reporting Service 9:180.

5. Anonymous. 2009. Meloidogyne chitwoodi and Meloidogyne fallax. EPPO Bull. 39:5-17.

6. Anonymous. 2011. Meloidogyne enterolobii. EPPO Bull. 41:329-339.

7. Anthony, F., Topart, P., Martinez, A., Silva, M., and Nicole, M. 2005. Hypersensitive-like reaction conferred by the Mex-1 resistance gene against Meloidogyne exigua in coffee. Plant Pathol. 54:476-482.

8. Barbosa, D. H. S. G., Vieira, H. D., Souza, R. M., Viana, A. P., and Silva, C. P. 2004. Field estimates of coffee yield losses and damage threshold by Meloidogyne exigua. Nematol. Bras. 28:49-54.

9. Barbosa, D. H. S. G., Souza, R. M., and Vieira, H. D. 2010. Field assessment of coffee (Coffea arabica L.) cultivars in Meloidogyne exiguainfested or -free fields in Rio de Janeiro State, Brazil. Crop Prot. 29:175177.

10. Bello, A., Robertson, L., Díez-Rojo, M. A., and Arias, M. 2005. A reevaluation of the geographical distribution of quarantine nematodes reported in Spain. Nematol. Medit. 33:209-216.

11. Bertrand, B., Aguilar, G., Bompard, E., Rafinon, A., and Anthony, F. 1997. Comportement agronomique et résistance aux principaux déprédateurs des lignées de Sarchimor et Catimor au Costa Rica. Plantations Recherche Développement 4:312-321.

12. Bird, A. F., and Rogers, G. E. 1965. Ultrastructural and histochemical studies of the cells producing the gelatinous matrix in Meloidogyne. Nematologica 11:231-238.

13. Bird, D. M., Williamson, V. M., Abad, P., McCarter, J., Danchin, E. G. J., Castagnone-Sereno, P., and Opperman, C. H. 2009. The genomes of rootknot nematodes. Annu. Rev. Phytopathol. 47:333-351.

14. Blok, V. C., Phillips, M. S., and Fargette, M. 1997. Comparison of se- 
quences from the ribosomal DNA intergenic region of Meloidogyne mayaguensis and other major tropical root-knot nematodes. J. Nematol. 29:16-22.

15. Bouisseau, M., Aribi, J., de Sousa, F. R., Carneiro, R. M. D. G., and Anthony, F. 2009. Resistance to Meloidogyne paranaensis in wild Coffea arabica. Trop. Plant Pathol. 34:38-41.

16. Brown, C. R. 2011. The contribution of traditional potato breeding to scientific potato improvement. Potato Res. 54:287-300.

17. Brown, C. R., Mojtahedi, H., James, S. J., Novy, R. G., and Love, S. L. 2006. Development and evaluation of potato breeding lines with introgressed resistance to Columbia root-knot nematode (Meloidogyne chitwoodi). Am. J. Potato Res. 83:1-8.

18. Brown, C. R., Mojtahedi, H., Zhang, L. H., and Riga, E. 2009. Independent resistant reactions expressed in root and tuber of potato breeding lines with introgressed resistance to Meloidogyne chitwoodi. Phytopathology 99:1085-1089.

19. Carneiro, R. G., Moritz, M. P., Mônaco, A. P. A., de Lima, A. C. C., and Santiago, D. C. 2006. Reação de cultivares de aveia às raças 1 e 3 de Meloidogyne incognita e a M. paranaensis. Nematol. Bras. 30:281-285.

20. Carneiro, R. M. D. G., Carneiro, R. G., Abrantes, I. M. O., Santos, M. S. N., and Almeida, M. R. A. 1996. Meloidogyne paranaensis n. sp. (Nemata: Meloidogynidae), a root-knot nematode parasitizing coffee in Brazil. J. Nematol. 28:177-189.

21. Carneiro, R. M. D. G., Tigano, M. S., Randig, O., Almeida, M. R. A., and Sarah, J. L. 2004. Identification and genetic diversity of Meloidogyne spp. (Tylenchida: Meloidogynidae) on coffee from Brazil, Central America and Hawaii. Nematology 6:287-298.

22. Castagnone-Sereno, P. 2012. Meloidogyne enterolobii (=M. mayaguensis): Profile of an emerging, highly pathogenic, root-knot nematode species. Nematology 14:133-138.

23. Castagnone-Sereno, P., Danchin, E. G. J., Deleury, E., Guillemaud, T., Malausa, T., and Abad, P. 2010. Genome-wide survey and analysis of microsatellites in nematodes, with a focus on the plant-parasitic species Meloidogyne incognita. BMC Gen. 11:598.

24. Castro, J. M. C., Campos, V. P., Pozza, E. A., Naves, R. L., Andrade, W. C., Jr., Dutra, M. R., Coimbra, J. L., Maximiniano, C., and Silva, J. R. C. 2008. Levantamento de fitonematóides em catezais do sul de Minas Gerais. Nematol. Bras. 32:56-64.

25. Charchar, J. M., and Santo, G. S. 2001. Effect of temperature on the embryogenic development and hatching of Meloidogyne chitwoodi races 1 and 2 and M. hapla. Nematol. Bras. 25:71-77.

26. Chen, Z. X., and Dickson, D. W. 1998. Review of Pasteuria penetrans: Biology, ecology, and biological control potential. J. Nematol. 30:313340.

27. Coll, P., Le Cadre, E., and Villenave, C. 2012. How are nematode communities affected during a conversion from conventional to organic farming in southern French vineyards? Nematology 14:665-676.

28. de Weerdt, M., Kox, L., Waeyenberge, L., Viaene, N., and Zijlstra, C. 2010. A real-time PCR assay to identify Meloidogyne minor. J. Phytopathol. 159:80-84.

29. den Nijs, L. J. M. F., Brinkman, H., and van der Sommen, A. T. C. 2004. A Dutch contribution to knowledge on phytosanitary risk and host status of various crops for Meloidogyne chitwoodi Golden et al., 1980 and M. fallax Karssen, 1996: An overview. Nematology 6:303-312.

30. Devran, Z. M., Mutlu, N., Özarslandan, A., and Elekcioglu, I. H. 2009. Identification and genetic diversity of Meloidogyne chitwoodi in potato production areas of Turkey. Nematropica 39:75-83.

31. Dias, M. C., Conceição, I. L., Abrantes, I., and Cunha, M. J. 2012. Solanum sisymbriifolium-A new approach for the management of plantparasitic nematodes. Eur. J. Plant Pathol. 133:171-179.

32. Dropkin, V. H. 1988. The concept of race in phytonematology. Annu. Rev. Phytopathol. 26:145-161.

33. Esbenshade, P. R., and Triantaphyllou, A. C. 1985. Use of enzyme phenotype for identification of Meloidogyne species. J. Nematol. 17:6-20.

34. Fargette, M., Lollier, V., Phillips, M., Blok, V., and Frutos, R. 2005. AFLP analysis of the genetic diversity of Meloidogyne chitwoodi and M. fallax, major agricultural pests. Comptes Rendus Biol. 328:455-462.

35. Ferris, H., Carlson, H. L., Viglierchio, D. R., Westerdahl, B. B., Wu, F. W., Anderson, C. E., Juurma, A., and Kirby, D. W. 1993. Host status of selected crops to Meloidogyne chitwoodi. J. Nematol. (Suppl.) 25:849857.

36. François, C., Kebdani, N., Barker, I., Tomlinson, J., Boonham, N., and Castagnone-Sereno, P. 2006. Towards specific diagnosis of plant-parasitic nematodes using DNA oligonucleotide microarray technology: A case study with the quarantine species Meloidogyne chitwoodi. Mol. Cell. Probes 20:64-69.

37. Gadoury, D. M., Andrews, J., Baumgartner, K., Burr, T., Kennelly, M. M., Lichens-Park, A., MacDonald, J., Savary, S., Scherm, H., Tally, A., and Wang, G. L. 2009. Disciplinary, institutional, funding, and demographic trends in plant pathology-What does the future hold for the profession? Plant Dis. 93:1228-1237.

38. Gamon, A., and Lenne, N. 2012. Meloidogyne chitwoodi and Meloidogyne fallax in France: Initial management experiences. EPPO Bull. 42:122-126.

39. Golden, A. M., O’Bannon, J. H., Santo, G. S., and Finley, A. M. 1980. Description and SEM observations of Meloidogyne chitwoodi n. sp. (Meloidogynidae). A root-knot nematode on potato in the Pacific Northwest. J. Nematol. 12:319-327.

40. Göldi, E. M. 1887. Relatório sôbre a moléstia do cafeeiro na provincia do Rio de Janeiro. Extrahido do VIII vol. dos. Archivos do Museu Nacional, Rio de Janeiro, Imprensa Nacional.

41. Gomes, V. M., Souza, R. M., Midorikawa, G., Miller, R., and Almeida, A. M. 2012. Guava decline: Evidence of nationwide incidence in Brazil. Nematropica 42:153-162.

42. Gomes, V. M., Souza, R. M., Mussi-Dias, V., da Silveira, S. F., and Dolinski, C. 2010. Guava decline: A complex disease involving Meloidogyne mayaguensis and Fusarium solani. J. Phytopathol. 159:45-50.

43. Goodell, P. B., and Ferris, H. 1989. Influence of environmental factors on the hatch and survival of Meloidogyne incognita. J. Nematol. 21:328-334.

44. Greco, N., and Inserra, R. N. 2008. Exotic and non-exotic nematode plant pests: A potential threat to the Italian agriculture and environment. Redia 91:103-109.

45. Hallmann, J., Frankenberg, A., Paffrath, A., and Schmidt, H. 2007. Occurrence and importance of plant-parasitic nematodes in organic farming in Germany. Nematology 9:869-879.

46. Hewezi, T. and Baum, T. J. 2013. Manipulation of plant cells by cyst and root-knot nematode effectors. Mol. Plant-Microbe Interact. 26:9-16.

47. Holtermann, M., Karssen, G., van den Elsen, S., van Megen, H., Bakker, J., and Helder, J. 2009. Small subunit rDNA-based phylogeny of the Tylenchida sheds light on relationships among some high-impact plantparasitic nematodes and the evolution of plant feeding. Phytopathology 99:227-235.

48. Holterman, M. H. M., Oggenfuss, M., Frey, J. E., and Kiewnick, S. 2012. Evaluation of high-resolution melting curve analysis as a new tool for root-knot nematode diagnostics. J. Phytopathol. 160:59-66.

49. Hu, M. X., Zhuo, K., and Liao, J. L. 2011. Multiplex PCR for the simultaneous identification and detection of Meloidogyne incognita, M. enterolobii, and $M$. javanica using DNA extracted directly from individual galls. Phytopathology 101:1270-1277.

50. Huang, G., Allen, R., Davis, E. L., Baum, T. J., and Hussey, R. S. 2006. Engineering broad root-knot nematode resistance in transgenic plants by RNAi silencing of a conserved and essential root-knot nematode parasitism gene. Proc. Natl. Acad. Sci. USA 103:14302-14306.

51. Humphreys, D. A., Williamson, V. M., Salazar, L., Flores-Chaves, L., and Gómez-Alpizar, L. 2012. Presence of Meloidogyne enterolobii Yang \& Eisenback $(=M$. mayaguensis $)$ in guava and acerola from Costa Rica. Nematology 14:199-207.

52. Humphreys-Pereira, D. A., and Elling, A. A. 2013. Intraspecific variability and genetic structure in Meloidogyne chitwoodi from the USA. Nematology 15:315-327.

53. Ingham, R. E., Hamm, P. B., Baune, M., David, N. L., and Wade, N. M. 2007. Control of Meloidogyne chitwoodi in potato with shank-injected metam sodium and other nematicides. J. Nematol. 39:161-168.

54. Ingham, R. E., Hamm, P. B., Williams, R. E., and Swanson, W. H. 2000. Control of Meloidogyne chitwoodi in potato with fumigant and nonfumigant nematicides. J. Nematol. (Suppl.) 32:556-565.

55. Ismail, A., Matthews, B. F., and Alkharouf, N. W. 2012. RKN lethal DB: A database for the identification of root knot nematode (Meloidogyne spp.) candidate lethal genes. Bioinformation 8:950-952.

56. Kaminski, K., Beckers, F., and Unger, J. G. 2012. Global internet trade of plants - legality and risks. EPPO Bull. 42:171-175.

57. Karssen, G. 1996. Description of Meloidogyne fallax n. sp. (Nematoda: Heteroderidae), a root-knot nematode from The Netherlands. Fund. Appl. Nematol. 19:593-599.

58. Karssen, G. 2002. The plant-parasitic nematode genus Meloidogyne Göldi, 1892 (Tylenchida) in Europe. Brill, Leiden, The Netherlands.

59. Karssen, G., Bolk, R. J., van Aelst, A. C., van den Beld, I., Kox, L. F. F., Korthals, G., Molendijk, L., Zijlstra, C., van Hoof, R., and Cook, R. 2004. Description of Meloidogyne minor $\mathrm{n}$. sp. (Nematoda: Meloidogynidae), a root-knot nematode associated with yellow patch disease in golf courses. Nematology 6:59-72.

60. Karssen, G., Liao, J., Kan, Z., van Heese, E. Y. J., and den Nijs, L. J. M. F. 2012. On the species status of the root-knot nematode Meloidogyne mayaguensis Rammah \& Hirschmann, 1988. ZooKeys 181:67-77.

61. Kiewnick, S., Dessimoz, M., and Franck, L. 2009. Effects of the Mi-1 and the $N$ root-knot nematode-resistance gene on infection and reproduction of Meloidogyne enterolobii on tomato and pepper cultivars. J. Nematol. 41:134-139. 
62. Kouassi, A. B., Kerlan, M. C., Caromel, B., Dantec, J. P., Fouville, D., Manzanares-Dauleux, M., Ellissèche, D., and Mugniéry, D. 2006. A major gene mapped on chromosome XII is the main factor of a quantitatively inherited resistance to Meloidogyne fallax in Solanum sparsipilum. Theor. Appl. Genet. 112:699-707.

63. Kouassi, A. B., Kerlan, M. C., Sobczak, M., Dantec, J. P., Rouaux, C., Ellissèche, D., and Mugniéry, D. 2004. Resistance to the root-knot nematode Meloidogyne fallax in Solanum sparsipilum: Analysis of the mechanisms. Nematology 6:389-400.

64. Lilley, C. J., Davies, L. J., and Urwin, P. E. 2012. RNA interference in plant parasitic nematodes: A summary of the current status. Parasitology 139:630-640.

65. Machado, A. R. T., Campos, V. A. C., da Silva, W. J. R., Campos, V. P., de Mattos Zeri, A. C., and Oliviera, D. F. 2012. Metabolic profiling in the roots of coffee plants exposed to the coffee root-knot nematode, Meloidogyne exigua. Eur. J. Plant Pathol. 134:431-441.

66. McClure, M. A., Nischwitz, C., Skantar, A. M., Schmitt, M. E., and Subbotin, S. E. 2012. Root-knot nematodes in golf course greens of the western United States. Plant Dis. 96:635-647.

67. Moens, M., Perry, R. N., and Starr, J. L. 2009. Meloidogyne species-A diverse group of novel and important plant parasites. In: Root-Knot Nematodes. R. N. Perry, M. Moens, and J. L. Starr, eds. CAB International, Wallingford, UK.

68. Mônaco, A. P. A., Carneiro, R. G., Kranz, W. M., Gomes, J. C., Scherer, A., Nakamura, K. C., Moritz, M. P., and Santiago, D. C. 2008. Reação de espécies de plantas daninhas a Meloidogyne paranaensis. Nematol. Bras. 32:279-284.

69. Moritz, M. P., Monaco, A., Carneiro, R. G., Scherer, A., Santiago, D. C., and Nora, T. D. 2009. Reação de cultivares de milho e soja a Meloidogyne paranaensis. Nematol. Bras. 33:94-98.

70. Morris, K. S., Horgan, F. G., Downes, M. J., and Griffin, C. T. 2011. The effect of temperature on hatch and activity of second-stage juveniles of the root-knot nematode, Meloidogyne minor, an emerging pest in northwest Europe. Nematology 13:985-993.

71. Mulet, K., Fargette, M., Richaud, M., Genson, G., and CastagnoneSereno, P. 2011. Isolation of microsatellites from an enriched genomic library of the plant-parasitic nematode Meloidogyne incognita and their detection in other root-knot nematode species. Eur. J. Plant Pathol. 129:501-505

72. Muniz, M. F. S., Campos, V. P., Almeida, M. R. A., Gomes, A. C. M. M., dos Santos, M. F., de Castro Mota, F., and Carneiro, R. M. D. G. 2009. Additional information on an atypical population of Meloidogyne exigua Göldi, 1887 (Tylenchida: Meloidogynidae) parasitizing rubber tree in Brazil. Nematology 11:95-106.

73. Muniz, M. F. S., Campos, V. P., Castagnone-Sereno, P., Castro, J. M. C., Almeida, M. R. A., and Carneiro, R. M. D. G. 2008. Diversity of Meloidogyne exigua (Tylenchida: Meloidogynidae) populations from coffee and rubber tree. Nematology 10:897-910.

74. Muniz, M. F. S., Campos, V. P., Moita, A. W., Gonçalves, W., Ameida, M. R. A., de Sousa, F. R., and Carneiro, R. M. D. G. 2009. Reaction of coffee genotypes to different populations of Meloidogyne spp.: Detection of a naturally virulent M. exigua population. Trop. Plant Pathol. 34:370-378.

75. Nischwitz, C., Skantar, A., Handoo, Z. A., Hult, M. N., Schmitt, M. E., and McClure, M. A. 2013. Occurrence of Meloidogyne fallax in North America, and molecular characterization of M. fallax and M. minor from U.S. golf course greens. Plant Dis. doi://dx.doi.org/10.1094?PDIS-03-130263-RE

76. Niu, J. H., Guo, Q. X., Jian, H., Chen, C. L., Yang, D., Liu, Q., and Guo, Y. D. 2011. Rapid detection of Meloidogyne spp. by LAMP assay in soil and roots. Crop Prot. 30:1063-1069.

77. Niu, J. H., Jian, H., Guo, Q. X., Chen, C. L., Wang, X. Y., Liu, Q., and Guo, Y. D. 2012. Evaluation of loop-mediated isothermal amplification (LAMP) assays based on 5S rDNA-IGS2 regions for detecting Meloidogyne enterolobii. Plant Pathol. 61:809-819.

78. Noir, S., Anthony, F., Bertrand, B., Combes, M. C., and Lashermes, P. 2003. Identification of a major gene (Mex-1) from Coffea canephora conferring resistance to Meloidogyne exigua in Coffea arabica. Plant Pathol. 52:97-103.

79. Norshie, P. M., Been, T. H., and Schomaker, C. H. 2011. Estimation of partial resistance in potato genotypes against Meloidogyne chitwoodi. Nematology 13:477-489.

80. O'Bannon, J. H., Santo, G. S., and Nyczepir, A. P. 1982. Host range of the Columbia root-knot nematode. Plant Dis. 66:1045-1048.

81. Opperman, C. H., Bird, D. M., Williamson, V. M., Rokhsar, D. S., Burke, M., Cohn, J., Cromer, J., Diener, S., Gajan, J., Graham, S., Houfek, T. D., Liu, Q., Mitros, T., Schaff, J., Schaffer, R., Scholl, E., Sosinski, B. R., Thomas, V. P., and Windham, E. 2008. Sequence and genetic map of Meloidogyne hapla: A compact nematode genome for plant parasitism. Proc. Natl. Acad. Sci. USA 105:14802-14807.
82. Ozarslandan, A., Devran, Z., Mutlu, N., and Elekcioglu, I. H. 2009. First report of Columbia root-knot nematode (Meloidogyne chitwoodi) in potato in Turkey. Plant Dis. 93:316.

83. Pereira, F. M., Souza, R. M., Souza, P. M., Dolinski, C., and Santos, G. K. 2009. Estimativa do impacto econômico e social direto de Meloidogyne mayaguensis na cultura da goiaba no Brasil. Nematol. Bras. 33:176-181.

84. Perry, R. N., Moens, M., and Starr, J. L. (eds.) 2009. Root-Knot Nematodes. CAB International, Wallingford, UK

85. Porazinska, D. L., Giblin-Davis, R. M., Esquivel, A., Powers, T. O., Sung, W., and Thomas, W. K. 2010. Ecometagenetics confirm high tropical rainforest nematode diversity. Mol. Ecol. 19:5521-5530.

86. Powers, T., Harris, T., Higgins, R., Mullin, P., Sutton, L., and Powers, K. 2011. MOTUs, morphology, and biodiversity estimation: A case study using nematodes of the suborder Criconematina and a conserved $18 \mathrm{~S}$ DNA barcode. J. Nematol. 43:35-48.

87. Powers, T. O., Mullin, P. G., Harris, T. S., Sutton, L. A., and Higgins, R. S. 2005. Incorporating molecular identification of Meloidogyne spp. into a large-scale regional nematode survey. J. Nematol. 37:226-235.

88. Rammah, A., and Hirschmann, H. 1988. Meloidogyne mayaguensis n. sp. (Meloidogynidae), a root-knot nematode from Puerto Rico. J. Nematol. 20:58-69.

89. Randig, O., Bongiovanni, M., Carneiro, R. M. D. G., and CastagnoneSereno, P. 2002. Genetic diversity of root-knot nematodes from Brazil and development of SCAR markers specific for the coffee-damaging species. Genome 45:862-870.

90. Randig, O., Deau, F., dos Santos, M. F. A., Tigano, M. S., Carneiro, R. M. D. G., and Castagnone-Sereno, P. 2009. A novel species-specific satellite DNA family in the invasive root-knot nematode Meloidogyne mayaguensis and its potential use for diagnostics. Eur. J. Plant Pathol. 125:485-495

91. Reed, G. H., Kent, J. O., and Wittwer, C. T. 2007. High-resolution DNA melting analysis for simple and efficient molecular diagnostics. Pharmacogenomics 8:597-608.

92. Rich, J. R., Brito, J. A., Kaur, R., and Ferrell, J. A. 2008. Weed species as hosts of Meloidogyne: A review. Nematropica 39:157-185.

93. Roberts, P. A. 1995. Conceptual and practical aspects of variability in root-knot nematodes related to host plant resistance. Annu. Rev. Phytopathol. 33:199-221.

94. Rocha, F. D., Campos, V. P., and de Souza, J. T. 2010. Variation in lipid reserves of second-stage juveniles of Meloidogyne exigua in a coffee field and its relationship with infectivity. Nematology 12:365-371.

95. Roese, A. D., Oliveira, R. D. L., and Oliveira, D. S. 2007. Variabilidade fisiológica em populações de Meloidogyne paranaensis. Fitopatol. Bras. 32:40-43

96. Sasser, J. N., and Freckman, D. W. 1987. A world perspective on nematology: The role of society. Pages 7-14 in: Vistas on Nematology. J. A. Veech and D. W. Dickson, eds. Society of Nematologists, Hyattsville, MD.

97. Silva, R. V., Oliviera, R. D. L., Ferreira, P. S., and Castro, D. B. 2008. Efeito do gene $M i$ na reprodução de populações de Meloidogyne exigua em tomateiro. Nematol. Bras. 32:150-153.

98. Souza, R. M. (ed.) 2008. Plant-Parasitic Nematodes of Coffee. Springer, Berlin, Germany.

99. Talavera, M., Sayadi, S., Chirosa-Ríos, M., Salmerón, T., Flor-Peregrín, E., and Verdejo-Lucas, S. 2012. Perception of the impact of root-knot nematode-induced diseases in horticultural protected crops of southeastern Spain. Nematology 14:517-527.

100. Taylor, L. R., Sasser, J. N., and Nelson, L. A. 1982. Relationships of climate and soil characteristics to geographical distribution of Meloidogyne species in agricultural soils. Cooperative Publication, Department of Plant Pathology, North Carolina State University and U.S. Agency for International Development, Raleigh, NC.

101. Thoden, T. C., Korthals, G. W., Visser, J., and van Gastel-Topper, W. 2012. A field study on the host status of different crops for Meloidogyne minor and its damage potential on potatoes. Nematology 14:277-284.

102. Tigano, M., de Siqueira, K., Castagnone-Sereno, P., Mulet, K., Queiroz, P., dos Santos, M., Teixeira, C., Almeida, M., Silva, J., and Carneiro, R. 2010. Genetic diversity of the root-knot nematode Meloidogyne enterolobii and development of a SCAR marker for this guava-damaging species. Plant Pathol. 59:1054-1061.

103. Tomita, N., Mori, Y., Kanda, H., and Notomi, T. 2008. Loop-mediated isothermal amplification (LAMP) of gene sequences and simple visual detection of products. Nature Prot. 3:877-882.

104. Turner, S. J., and Fleming, C. C. 2005. Meloidogyne minor: A threat to temperate crops? Comm. Appl. Biol. Sci. Ghent University 70:885-887.

105. van der Beek, J. G., and Karssen, G. 1997. Interspecific hybridization of meiotic parthenogenetic Meloidogyne chitwoodi and M. fallax. Phytopathology 87:1061-1066. 
106. van der Beek, J. G., Maas, P. W. T., Janssen, G. J. W., Zijlstra, C., and van Silfhout, C. H. 1999. A pathotype system to describe intraspecific variation in pathogenicity of Meloidogyne chitwoodi. J. Nematol. 31:386-392.

107. van der Beek, J. G., and Mugniéry, D. 2008. Variation in host status of Brassica spp. for isolates of the Columbia root-knot nematode, Meloidogyne chitwoodi, and potential mechanisms. Nematology 10:767-775.

108. van der Beek, J. G., and Poleij, L. M. 2008. Evidence for pathotype mixtures on Solanum bulbocastanum in Meloidogyne chitwoodi but not in M. fallax. Nematology 10:575-584.

109. van Megen, H., van den Elsen, S., Holtermann, M., Karssen, G., Mooyman, P., Bongers, T., Holovachov, O., Bakker, J., and Helder, J. 2009. A phylogenetic tree based on about 1200 full-length small subunit ribosomal DNA sequences. Nematology 11:927-950.

110. van Meggelen, J. C., Karssen, G., Janssen, G. J. W., Verkerk-Bakker, B., and Janssen, R. 1994. A new race of Meloidogyne chitwoodi Golden, O’Bannon, Santo \& Finley, 1980? Fund. Appl. Nematol. 17:93.

111. Vandenbossche, B., Viaene, N., de Sutter, N., Maes, M., Karssen, G., and Bert, W. 2011. Diversity and incidence of plant-parasitic nematodes in Belgian turf grass. Nematology 13:245-256.
112. Viaene, N., Mahieu, T., and de la Peña, E. 2007. Distribution of Meloidogyne chitwoodi in potato tubers and comparison of extraction methods. Nematology 9:143-150.

113. Wesemael, W. M. L., and Moens, M. 2008. Vertical distribution of the plant-parasitic nematode, Meloidogyne chitwoodi, under field crops. Eur. J. Plant Pathol. 120:249-257.

114. Wesemael, W. M. L., Perry, R. N., and Moens, M. 2006. The influence of root diffusate and host age on hatching of the root-knot nematodes, Meloidogyne chitwoodi and M. fallax. Nematology 8:895-902.

115. Wesemael, W. M. L., Viaene, N., and Moens, M. 2011. Root-knot nematodes (Meloidogyne spp.) in Europe. Nematology 13:3-16.

116. Wyss, U., Grundler, F. M. W., and Munch, A. 1992. The parasitic behaviour of second-stage juveniles of Meloidogyne incognita in roots of Arabidopsis thaliana. Nematologica 38:98-111.

117. Yang, B., and Eisenback, J. D. 1983. Meloidogyne enterolobii n. sp. (Meloidogynidae), a root-knot nematode parasitizing pacara earpod tree in China. J. Nematol. 15:381-391.

118. Zijlstra, C., and van Hoof, R. A. 2006. A multiplex real-time polymerase chain reaction (TaqMan) assay for the simultaneous detection of Meloidogyne chitwoodi and M. fallax. Phytopathology 96:1255-1262. 